\title{
Challenging Behavior, Parental Conflict and Community Violence in Students with Aggressive Behavior
}

Conducta desafiante, conflicto parental y violencia en comunidad en estudiantes con comportamiento agresivo

Angel Alberto Valdés Cuervo ${ }^{1 *}$, Jesús Tánori Quintana ${ }^{1}$, Ernesto Alonso Carlos Martínez², Teodoro Rafael Wendlandt Amezaga ${ }^{1}$

\begin{abstract}
The effects of the presence of challenging behavior problems, parental conflict and violence in the community were determined by the probability of occurrence of bullying behaviors in elementary students. 664 students participated in the study, of whom $80(12.04 \%)$ were identified as aggressors. 80 students with no reports of attacks were later selected randomly for comparison. Using logistic regression, it was found that the variables studied manifest significant differences between the student groups with and without aggressive behavior toward peers $\left(R^{2}=.39\right)$. Challenging behavior $(\mathrm{OR}=7.83)$, parental conflict $(O R=3.77)$ and Community Violence $(O R=5.36)$ increase the probability of belonging to the group of aggressors. We conclude that it is necessary to analyze the bullying from an ecological framework that considers variables located in the contexts in which individuals interact.

\section{Resumen}

Se buscó establecer la relación de la presencia de conductas desafiantes, conflictos entre padres y violencia en la comunidad con la probabilidad de ocurrencia de comportamientos de intimidación en estudiantes de primaria. En este estudio participaron 664, de los cuales 80 (12.04\%) fueron identificados como agresores; posteriormente se incluyeron al azar 80 estudiantes sin informes de ataques como grupo control. Usando la regresión lógica, se encontró que las variables estudiadas manifiestan diferencias significativas entre los grupos de estudiantes con y sin comportamiento agresivo hacia los compañeros $\left(R^{2}=.39\right)$. El comportamiento desafiante $(\mathrm{OR}=7.83)$, el conflicto parental $(\mathrm{OR}=3.77)$ y la violencia comunitaria $(O R=5.36)$ aumentan la probabilidad de pertenecer al grupo de agresores. Concluimos que es necesario analizar el bullying desde un marco ecológico que considera variables ubicadas en los contextos en los que interactúan los individuos.
\end{abstract}

\section{Keywords:}

Family, neighborhood, school violence, bullying.

\section{Palabras Claves:}

Familia, comunidad, violencia escolar, bullying.

1. Instituto Tecnológico de Sonora, Obregón, Mexico.

2. Instituto Tecnológico Superior de Cajeme, Obregón, Mexico.

"Corresponding author: angel.valdes@itson.edu.mx

Manuscript received 05-10-2015; revised 04-08-2017; accepted 22-09-2017.

\section{Introduction}

School violence affects negatively both the learning environment and the role of educational institutions on the formation of values, attitudes and pro-social behaviors that allow children and adolescents to live with others based on tolerance, respect and equity (Elliot, 2008; Ortega \& Del Rey, 2008). Studies in Mexico show that violence among students is a problem that affects the educational institutions of the country (Castillo \& Pacheco, 2008; Aguilera, Muñoz, \& Orozco, 2007; Muñoz, 2008; Organization for Economic Co-operation 
and Development [OCDE], 2017; Román \& Murillo, 2011; Valdés \& Carlos, 2017).

Bullying differs from other forms of aggression because of its systematic nature and its manifestation in the context of interpersonal relationships with marked asymmetries of power between the perpetrator and the victim (Rodkin, Espelage, \& Hanish, 2015; Volk, Dane, \& Marini, 2014). Among other negative effects, this problem leads to decreased academic performance, emotional disorders, and suicide attempts for victims (McDougall \& Vaillancourt, 2015; O'Brennan, Bradshaw, \& Sawyer, 2009). The attackers also are affected, as they show social adjustment difficulties during adolescence and adulthood, which are manifested in substance abuse, employment difficulties, violence in relationships and antisocial behavior (Farrington, 1993; Kim, Catalano, Haggerty, \& Abbott, 2011; Olweus, 2011; Pearce, 2008; Valdebenito, Ttofi, \& Eisner, 2015).

This study assumes it is necessary to address bullying from an ecological perspective since it is considered to be the result of interactions in which students operates within different contexts. This implies that there are characteristics of the student, family, school and community that are risk factors for the presence of bullying (Hong \& Espelage, 2012; Swearer \& Hymel, 2015).

Based on the preceding, this study investigated the relationship of variables located in the individual (challenging behavior), in the family (parental conflict) and community (community violence) with bullying in elementary school students. Although there are studies that address the relationship of these variables with bullying in the international literature (Bowes, Maughan, Caspi, Moffitt, \& Arseneault, 2010; Chang, Wang, \& Tsai, 2016; Kokkinos \& Panayiotou, 2004; Mann, Kristjansson, Sigfusdottir, \& Smith, 2015; Martínez, Amador, Moreno, \& Musitu, 2011) it should be noted that few studies address this topic in Mexico (Pech, 2010; Saucedo, 2005; Valdés, Carlos, Tánori, \& Madrid, 2016). Consequently, it is valuable to establish the relationship of these variables to bullying in the context of Mexican elementary schools.

Challenging behavior is manifested in a stable pattern of anger, violations of social rules, and direct or indirect confrontation with authority figures (Sutton, Reeves, \& Keogh, 2000). The literature suggests that these behavioral problems relate positively with bullying (Cho, Hendrickson, \& Mock, 2009; Rose, \& Espelage, 2012; Van Cleave \& Davis, 2006) and that when these two problems overlap, aggressive behavior is more stable over time (Pepler, Jiang, Craig, \& Connolly, 2008; Wolke, Woods, Bloomfield, \& Karstadt, 2000).

Parental conflict is related to parents showing less emotional availability and involvement with children (Margolin, Gordis, \& John, 2001; Sturge-Apple, Davies, \& Cummings, 2006; Werneck, Eder, Yanagida,
\& Rollett, 2014), excessive psychological control and inconsistent discipline practices (Azam \& Hanif, 2011; McCoy, George, Cummings, \& Davies, 2013). This conflict, which has a negative effect on parenting practices, favors the presence of externalized behavior problems (aggression, bullying) and internalization (depression, anxiety) in children (Buehler, Lange, \& Franck, 2007; Kitzmann, Gaylord, Holt, \& Kenny, 2003; Lee, Wesbecher, Lee, \& Lee, 2015). It also damages adolescents' and children's sense of family identity and safety, effects that are exacerbated when conflict is common, if it is handled in a hostile way and when it relates to or involves children (Cummings, Goekemorey, \& Papp, 2003; Lindsey, Colwell, Frabutt, \& McKinnon-Lewis, 2006).

Because interactions established within the community contribute to the internalization of expectations, values and social norms, the community exercises a major influence on the emotional development of adolescents. The influence of the community is investigated through three elements: sense of belonging, feelings of safety and exposure to violence (Zani, Cicognani, \& Albanesi, 2001). There is evidence that the perception of danger in the place where one lives influences the presence of aggressive behavior in young people (Frías-Armenta, Duron, \& Castro, 2011; Low \& Espegale, 2014; Mann et al., 2015).

We addressed adolescent exposure to various types of violence in the community, including both personal experiences of aggression and exposure to incidents targeting other people who are known victims in their community. Exposure to violence is related to the presence of behavioral problems such as bullying in adolescents (Bacchini, Esposito, \& Affuso, 2009; Chaux, Molano, \& Podlesky, 2009; Lynch, 2003; Swearer \& Hymel, 2015). A conflictive atmosphere in the community leads to violence legitimization, and, therefore, the existence of aggressors and victims becomes perceived as standard within schools (Chang et al., 2016; Chaux et al., 2009; Phillips, 2003).

This study set out to determine the effects of the presence of challenging behavior problems, parental conflict and exposure to violence in the community on the likelihood of aggressive behavior by elementary students towards their peers. It is hypothesized that the above variables significantly increase the likelihood of students behaving aggressively toward their peers.

\section{Method}

\section{Participants}

In a non-probabilistic way, 664 students enrolled in grades 4 to 6 in 12 public elementary schools from four school zones (three per school zone) of a city in northwestern Mexico were selected. 80 (12.04\%) students were identified as aggressors by the criterion that their average 
score was $\geq 2$ (Sometimes, three or four times a month) on the measuring scale of violence among students. Of these, 45 (56.25\%) were male and 35 (43.75\%) female. Their average age was 13.8 years $(S D=.86)$.

Of the remaining 584 students, who were not identified as aggressors, a subsample randomly selected 80 in order to perform analyses in groups of similar size. This group was composed of $42(52.5 \%)$ males and $38(47.5 \%)$ females with an average age of 13.6 $(S D=1.13)$.

\section{Instruments}

Violence among students. The self-report scale developed by Valdés and Carlos (2017) was used, in which students were questioned about how often they assaulted weaker students during the last month (e.g. Hitting peers, or Insulting their classmates). This instrument consists of six items that are answered by a Likert-type scale with five response options 0 (Never), 1 (Almost never, once or twice a month), 2 (Sometimes, three or four times a month), 3 (Almost always, five to seven times a month) and 4 (Always, more than seven times a month).

A confirmatory factor analysis demonstrated that the scale is a one-dimensional model to sustainably and empirically measure the construct already mentioned $\left(X^{2}=19.73, p=.019 ;\right.$ AGFI $=.97$; CFI $=.99$; RMSEA $=.04$, IC 90 [.02 - .07]). Cronbach's alpha was .83.

Challenging behavior. This instrument was developed by Sutton et al. (2000). This study used the subscale that measures the presence of challenging behavior through 11 items (e.g. I disobey the instructions and rules of adults). Using factor analysis with Oblimin maximum likelihood and rotation the factor structure of the scale was confirmed $\left(X^{2}=850.42, p<.000\right.$; KMO $=.83$ ) which was able to explain $62 \%$ of the variance of scores. Cronbach's Alpha, which demonstrates the reliability of the measurement scale, was .87.

The instrument utilized Likert-type scales with five response options 0 (Never), 1 (Almost never), 2 (Sometimes), 3 (Almost always) and 4 (Always). From the average score on the scale, students were classified into two groups: without challenging behaviors $(M \leq$ 1 ) and with challenging behaviors $(M>1)$.

Parental conflict. We used the subscale of the instrument developed by Grych, Seid and Fincham (1992), which used five items to assess childrens' perception of the frequency and intensity of parental conflict (e.g. I often see my parents arguing, My parents go crazy when arguing). An exploratory factorial analysis with Oblimin maximum likelihood and rotation, modeled the one-dimensional character of the scale $\left(X^{2}\right.$ $=506.50, p<.000 ; \mathrm{KMO}=.83$ ), which explained $60 \%$ of the variance of the scores. The reliability of the scores measured by Cronbach's Alpha was .90.

The instrument used a Likert-type scales with four response options: 0 (Strongly disagree), 1 (Disagree), 2 (Disagree) and 3 (Strongly agree). According to the average total scores on the scale, students were classified into a first group, which includes those who expressed a perception of low parental conflict ( $M \leq$ 1 ) and a second group, which reflect a high level of parental conflict $(M>1)$.

Exposure to violence in the community. An instrument based on the review of developed instruments that measured related aspects was developed for this study (Frías-Armenta, López-Escobar, \& Díaz-Méndez, 2003; Zani et al., 2001). Seven risk situations are presented to the student (e.g. Fights in the neighborhood, Presence of gangs) and then they're asked to select the option that best represents how often this situation occurs in their community.

It was answered by a Likert-type scale with five response options 0 (Never), 1 (Almost never), 2 (Sometimes), 3 (Often) and 4 (Always). Average scores were used to form a group of students with low exposure to violence $(M \leq 1)$ and another group with high exposure $(M>1)$. The measurement reliability with Cronbach's Alpha was .77.

\section{Procedure}

After presenting the study objective, we obtained authorization from school authorities for access. The written and informed consent of the parents of students who participated in the study was also required. Finally, we requested the voluntary cooperation of the students, guaranteeing them confidentiality.

In data analysis, descriptive and inferential statistics were used, particularly logistic regression. The calculation of the regression model was conducted with support from SPSS software v. 22.

\section{Results}

Table 1 shows that the predictive variables differ significantly between groups of students with and without reports of aggression toward peers. The group that reports higher levels of aggression has a higher proportion of students with challenging behaviors, high parental conflict and greater exposure to violence in the community. 
Table 1

Frequencies of the predictive variables of aggression in elementary students

\begin{tabular}{|c|c|c|c|c|c|c|}
\hline \multirow[b]{2}{*}{ Variable } & & \multicolumn{2}{|c|}{ Not aggressors $(n=80)$} & \multicolumn{2}{|c|}{ Aggressors $(n=80)$} & \multirow[b]{2}{*}{$X^{2(1)}$} \\
\hline & & $n$ & $\%$ & $n$ & $\%$ & \\
\hline \multicolumn{7}{|c|}{ Challenging behavior } \\
\hline & Absence & 57 & 71.25 & 16 & 20 & $40.93^{* * *}$ \\
\hline & Presence & 23 & 28.75 & 64 & 80 & \\
\hline \multicolumn{7}{|c|}{ Parental conflict } \\
\hline & Low & 24 & 30 & 6 & 7.5 & $13.55^{* * *}$ \\
\hline & High & 56 & 70 & 74 & 92.5 & \\
\hline \multicolumn{7}{|c|}{ Violence in the community } \\
\hline & Low & 13 & 16.25 & 5 & 6.25 & $9.04 * *$ \\
\hline & High & 67 & 83.75 & 75 & 93.75 & \\
\hline
\end{tabular}

$* p<.05 . * * p<.01 . * * * p<.001$.

The $R^{2}$ value of .39 shows that the predictive variables integrate a model with better predictive power than the base model. Hosmer-Lemeshow's test $\left(X^{2}=\right.$ 1.178, $d f=4, p=.88$ ) was not significant, indicating that there are no differences in the current distribution and the predicted values of the dependent variable.

Table 2

Summary of logistic regression analysis for predicting assault toward pairs

\begin{tabular}{lcccc}
\hline Variables & $B$ & $E S$ & $O R$ & Wald's Statistic \\
\hline Challenging behavior & 2.06 & .38 & 7.83 & $28.96 *$ \\
Parental conflict & 1.33 & .54 & 3.77 & $5.38 *$ \\
Community violence & 1.68 & .85 & 5.36 & $3.87 *$ \\
\hline
\end{tabular}

$* p<.05$.

All Beta coefficient values were significantly positive, implying that the probability of belonging to the group of aggressors and the incidence of challenging behaviors, perception of parental conflict and exposure to violence in the community were increased (see Table 2).

Predictive variables allowed the proper classification of $76.4 \%$ of students in the groups of aggressors and non-aggressors, which is considered acceptable for an analysis of this type (Cea, 2004; Ho, 2014). It should be noted they present slightly better discriminative power to identify aggressors than nonaggressors (see Table 3 ).

Table 3

Analysis of the classification aggressors and not aggressor's groups

\begin{tabular}{lccccc}
\hline \multirow{2}{*}{ Current membership group } & \multicolumn{3}{c}{ Predicted group membership } \\
\cline { 3 - 6 } & $n$ & $n$ & Aggressors & Not aggressors \\
\cline { 3 - 6 } & 80 & 63 & 78.7 & 18 & 21.3 \\
\hline Aggressors & 80 & 20 & 75 & 60 & 25 \\
\hline Not aggressors & &
\end{tabular}

Note. Globally correctly classifies $76.4 \%$ of students

\section{Discussion}

The present study analyzes the effects on elementary students of the presence of challenging behavior problems, parental conflict and exposure to violence in the community on the likelihood of aggressive behavior towards their peers. The results support the hypothesis of the study in the sense that they suggest that both challenging behavior problems, such as parental conflict and exposure to violence in the community make up a model that predicts the presence of aggressive behavior toward peers in elementary students. These findings reaffirm the importance of addressing bullying from an ecological framework that considers the effects of variables located in various contexts where the individual grows up (Hong \& Espelage, 2012; Swearer \& Hymel, 2015).

Matching reports in the literature, it was found that behavioral problems increase the likelihood of students to bully their peers (Cho et al., 2009; Rose, \& Espelage, 2012; Verlinden et al., 2015), which suggests that bullying in some children is the manifestation of a symptom within a pattern of maladaptive behaviors (Cook, Williams, Guerra, Kim, \& Sadek, 2010; Fanti \& Kimonis, 2012). Although this requires more investigation, it suggests that these students form part of the group of socially marginalized aggressors, who experience little acceptance and praise from peers (Farmer et al., 2010; Swearer \& Hymel, 2015; Peeters, Cillessen, \& Scholte, 2010).

It was found that perception of parental conflict increases the likelihood of the student developing bullying behaviors. This is consistent with reports in the literature which suggest frequent and hostile parental conflict is related to the presence in the children of aggressive behavior toward peers at school (Buehler et al., 2007; Kitzmann et al., 2003; Lee et al., 2015). Parental conflict explains the presence of aggressive 
behavior of children through their observation of aggressive parental models (Bandura, 1973) and because of the frustration associated with this situation, which they channel to aggression towards others (Dollard, Miller, Dood, Mowrer, \& Sears, 1939).

Lastly, the results suggest that exposure to violence in the community increases the likelihood of students behaving like bullies, which is consistent with the literature (Bacchini et al., 2009; Chang et al., 2016; Chaux et al., 2009; Lynch, 2003; Turner, Shattuck, Hamby, \& Finkelhor, 2013). Interestingly, the impact of this variable was greater than the presence of parental conflict which is a closer variable to child development. This suggests that interaction in extra-family social contexts, especially the community, has an important influence on the formation and expression of moral values, social norms and behavioral patterns (Lenzi et al., 2012; Schmidt, Pierce, \& Stoddard, 2016; Vieno, Santinello, Pastore, \& Perkins, 2007).

\section{Conclusions}

We conclude that the analysis of bullying from an ecological perspective is fruitful as it allows us to consider the impact of variables located in different contexts of individual development. From the results, we conclude that measures to prevent bullying should include: interventions, a focus on developing students' pro-social behavior, the strengthening of family life, and a reduction of the various manifestations of violence in the community. Our finding concerning the influence of exposure to violence in the community on the presence of bullying is particularly striking because it is a subject about which there have been few studies in Mexico, despite the high levels of violence in many communities and regions throughout the country. This shows that, for the prevention of bullying, public policies should be developed to prevent violence at the societal level as well as to strengthen the economic, cultural and social capital of communities.

The present study provides knowledge that can be useful for the prevention of bullying in schools. Nonetheless, it does present limitations, including the fact that we didn't consider interactions between variables, which would establish their share effects on the problem of bullying. Each context variable should also be integrated to allow for a broader perspective of violence among students. The study has a cross-sectional design that doesn't allow us to establish causal relation among variables. We suggest future studies be undertaken with an experimental and longitudinal design.

\section{References}

Aguilera, M. A., Muñoz, G., \& Orozco, A. (2007). Disciplina, violencia y consumo de sustancias nocivas a la salud en escuelas primarias y secundarias de México [Discipline, violence and substance use harmful to health in primary schools and secondary schools of Mexico]. México: INEE. Retrieved from http://publicaciones.inee.edu. $m x /$ buscadorPub/P1/D/230/P1D230.pdf

Azam, A., \& Hanif, R. (2011). Impact of parents' marital conflicts on parental attachment and social competence of adolescent. European Journal of Developmental Psychology, 8(2), 157-170. doi: 10.1080/17405620903332039

Bacchini, D., Esposito, G., \& Affuso, G. (2009). Social experience and school bullying. Journal of Community \& Applied Social Psychology, 19(1), 17-32. doi: 10.1002/casp.975

Bandura, A. (1973). Aggression: A social learning theory analysis. Englewood Cliffs, N.J.: Prentice Hall.

Bowes, L., Maughan, B., Caspi, A., Moffitt, T. E., \& Arseneault, L. (2010). Families promote emotional and behavioural resilience to bullying: evidence of an environmental effect. Journal of Child Psychology and Psychiatry, 51(7), 809-817. doi: 10.1111/j.1469-7610.2010.02216.x

Buehler, C., Lange, G., \& Franck, K. L. (2007). Adolescents' cognitive and emotional responses to marital hostility. Child Development, 78(3), 775789. doi: 10.1111/j.1467-8624.2007.01032.x

Castillo, C., \& Pacheco, M. M. (2008). Perfil del maltrato (bullying) entre estudiantes de secundaria en la ciudad de Mérida, Yucatán. Revista Mexicana de Investigación Educativa, 13(38), 825-842.

Cea, M. A. (2004). Análisis multivariable. Teoría y práctica en la investigación social. Madrid: Síntesis.

Chang, L. Y., Wang, M. Y., \& Tsai, P. S. (2016). Neighborhood disadvantage and physical aggression in children and adolescents: A systematic review and meta-analysis of multilevel studies. Aggressive Behavior, 42(5), 441-454. doi: 10.1002/ab.21641

Chaux, E., Molano, A., \& Podlesky, P. (2009). Socioeconomic, socio-political and socio-emotional variables explaining school bullying: a countrywide multilevel analysis. Aggressive Behavior, 35(6), 520-529. doi: 10.1002/ab.20320

Cho, J. I., Hendrickson, J. M., \& Mock, D. R. (2009). Bullying status and behavior patterns of preadolescents and adolescents with behavioral disorders. Education and Treatment of Children, 32(4), 655-671. 
Cook, C. R., Williams, K. R., Guerra, N. G., Kim, T. E., \& Sadek, S. (2010). Predictors of bullying and victimization in childhood and adolescence: A meta-analytic investigation. School Psychology Quarterly, 25(2), 65-83. doi: 10.1037/a0020149

Cummings, E. M., Goeke-morey, M. C., \& Papp, L. M. (2003). Children's responses to everyday marital conflict tactics in the home. Child Development, 74(6), 1918-1929. doi: 10.1046/j.1467-8624.2003.00646.x

Dollard, J., Miller, N. E., Doob, L. W., Mowrer, O. H., \& Sears, R. R. (1939). Frustration and aggression. New Haven: Yale University Press.

Elliot, M. (2008). Intimidadores y víctimas. In M. Elliot (Ed.), Intimidación. Una guía práctica para combatir el miedo en las escuelas (pp. 39-55). México: Fondo de Cultura Económica.

Fanti, K. A., \& Kimonis, E. R. (2012). Bullying and victimization: The role of conduct problems and psychopathic traits. Journal of Research on Adolescence, 22(4), 617-631. doi: 10.1111/j.1532-7795.2012.00809.x

Farmer, T. W., Petrin, R. A., Robertson, D. L., Fraser, M. W., Hall, C. M., Day, S. H., \& Dadisman, K. (2010). Peer relations of bullies, bully-victims, and victims: The two social worlds of bullying in second-grade classrooms. The Elementary School Journal, 110(3), 364-392. doi: 10.1086/648983

Farrington, D. P. (1993). Understanding and Preventing Bullying. Crime and Justice, 17, 381-458. doi: 10.1086/449217

Frías-Armenta, M., Durón, F., \& Castro, D. (2011). Justicia restaurativa: Evaluación de los factores comunitarios. Revista Mexicana de Psicología, 28(2), 217-225.

Frías-Armenta, M., López-Escobar, A. E., \& DíazMéndez, S. G. (2003). Predictores de la conducta antisocial juvenil: un modelo ecológico. Estudos de Psicologia (Natal), 8(1), 15-24. doi: 10.1590/ S1413-294X2003000100003

Grych, J. H., Seid, M., \& Fincham, F. D. (1992). Assessing Marital Conflict from the Child's Perspective: The Children's Perception of Interparental Conflict Scale. Child Development, 63(3), 558-572. doi: 10.1111/j.1467-8624.1992.tb01646.x

Ho, R. (2014). Handbook of univariate and multivariate data analysis with IBM SPSS (2 ${ }^{\text {th }}$ ed.). Florida, US: Taylor \& Francis Group.

Hong, J. S., \& Espelage, D. L. (2012). A review of research on bullying and peer victimization in school: An ecological system analysis. Aggression and Violent Behavior, 17(4), 311-322. doi: 10.1016/j.avb.2012.03.003
Kim, M. J., Catalano, R. F., Haggerty, K. P., \& Abbott, R. D. (2011). Bullying at elementary school and problem behaviour in young adulthood: A study of bullying, violence and substance use from age 11 to age 21. Criminal Behaviour and Mental Health, 21(2), 136-144. doi: 10.1002/cbm.804

Kitzmann, K. M., Gaylord, N. K., Holt, A. R., \& Kenny, E. D. (2003). Child witnesses to domestic violence: A meta-analytic review. Journal of Consulting and Clinical Psychology, 71(2), 339-352. doi: 10.1037/0022-006x.71.2.339

Kokkinos, C. M., \& Panayiotou, G. (2004). Predicting bullying and victimization among early adolescents: Associations with disruptive behavior disorders. Aggressive Behavior, 30(6), 520-533. doi: 10.1002/ab.20055

Lee, J.-y., Wesbecher, K., Lee, M., \& Lee, J. (2015). The mediation effects of dysfunctional beliefs and emotional regulation on children's perceived parentalconflictandinternalizing and externalizing problems. School Psychology International, 36(5), 447-466. doi: 10.1177/0143034315602525

Lenzi, M., Vieno, A., Perkins, D. D., Pastore, M., Santinello, M., \& Mazzardis, S. (2012). Perceived Neighborhood Social Resources as Determinants of Prosocial Behavior in Early Adolescence. American Journal of Community Psychology, 50(12), 37-49. doi: 10.1007/s10464-011-9470-X

Lindsey, E. W., Colwell, M. J., Frabutt, J. M., \& MacKinnonLewis, C. (2006). Family conflict in divorced and non-divorced families: Potential consequences for boys' friendship status and friendship quality. Journal of Social and Personal Relationships, 23(1), 45-63. doi: 10.1177/0265407506060177

Low, S., \& Espelage, D. (2014). Conduits from community violence exposure to peer aggression and victimization: Contributions of parental monitoring, impulsivity, and deviancy. Journal of Counseling Psychology, 61(2), 221-231. doi: $10.1037 / \mathrm{a} 0035207$

Lynch, M. (2003). Consequences of Children's Exposure to Community Violence. Clinical Child and Family Psychology Review, 6(4), 265-274. doi: 10.1023/B:CCFP.0000006293.77143.e1

Mann, M. J., Kristjansson, A. L., Sigfusdottir, I. D., \& Smith, M. L. (2015). The Role of Community, Family, Peer, and School Factors in Group Bullying: Implications for School-Based Intervention. Journal of School Health, 85(7), 477-486. doi: 10.1111/josh.12270

Margolin, G., Gordis, E. B., \& John, R. S. (2001). Coparenting: A link between marital conflict and parenting in two-parent families. Journal of Family Psychology, 15(1), 3-21. doi: 10.1037/0893-3200.15.1.3 
Martínez, B., Amador, L. V., Moreno. D., \& Musitu, G. (2011). Implicación y participación comunitaria y ajuste psicosocial en adolescentes. Psicología y Salud, 21(2), 205-214.

McCoy, K. P., George, M. R. W., Cummings, E. M., \& Davies, P. T. (2013). Constructive and Destructive Marital Conflict, Parenting, and Children's School and Social Adjustment. Social Development, 22(4), 641-662. doi: 10.1111/sode.12015

McDougall, P., \& Vaillancourt, T. (2015). Long-term adult outcomes of peer victimization in childhood and adolescence: Pathways to adjustment and maladjustment. American Psychologist, 70(4), 300-310. doi: 10.1037/a0039174

Muñoz, G. (2008). Violencia escolar en México y otros países: comparaciones a partir de los resultados del Instituto Nacional para la Evaluación de la Educación. Revista Mexicana de Investigación Educativa, 13(39), 1195-1228.

O’Brennan, L. M., Bradshaw, C. P., \& Sawyer, A. L. (2009). Examining developmental differences in the social-emotional problems among frequent bullies, victims, and bully/victims. Psychology in the Schools, 46(2), 100-115. doi: 10.1002/ pits.20357

Olweus, D. (2011). Bullying at school and later criminality: Findings from three Swedish community samples of males. Criminal Behaviour and Mental Health, 21(2), 151-156. doi: 10.1002/cbm. 806

Organization for Economic Co-operation and Development [OCDE]. (2017), PISA 2015 Results (Volume III): Students' Well-Being, Paris, France: OECD Publishing. doi: 10.1787/9789264273856-en

Ortega, R. O, \& Del Rey, R. (2008). La violencia escolar. Estrategias de prevención ( $4^{\text {ta }} \mathrm{Ed}$.). Barcelona: GRAO.

Pearce, J. (2008). ¿Qué se puede hacer con el agresor? In M. Elliot (Ed.), Intimidación. Una guía práctica para combatir el miedo en las escuelas (pp. 157186). Mexico: Fondo de Cultura Económica.

Pech, E. (2010). Dificultades de interacción social y violencia en migrantes escolares de secundarias urbanas yucatecas. El Cotidiano, 161, 105-117.

Peeters, M., Cillessen, A. H. N., \& Scholte, R. H. J. (2010). Clueless or Powerful? Identifying Subtypes of Bullies in Adolescence. Journal of Youth and Adolescence, 39(9), 1041-1052. doi: 10.1007/s10964-009-9478-9

Pepler, D., Jiang, D., Craig, W., \& Connolly, J. (2008). Developmental Trajectories of Bullying and Associated Factors. Child Development, 79(2), 325338. doi: 10.1111/j.1467-8624.2007.01128.x
Phillips, C. (2003). Who's Who in the Pecking Order? Aggression and 'Normal Violence' in the Lives of Girls and Boys. The British Journal of Criminology, 43(4), 710-728. doi: 10.1093/bjc/43.4.710

Rodkin, P. C., Espelage, D. L., \& Hanish, L. D. (2015). A relational framework for understanding bullying: Developmental antecedents and outcomes. American Psychologist, 70(4), 311-321. doi: $10.1037 / \mathrm{a} 0038658$

Román, M., \& Murillo, F. (2011). América Latina: violencia entre estudiantes y desempeño escolar. Revista CEPAL, 104, 37-54. Recuperado de doi: 123456789/1377

Rose, C. A., \& Espelage, D. L. (2012). Risk and Protective Factors Associated with the Bullying Involvement of Students with Emotional and Behavioral Disorders. Behavioral Disorders, 37(3), 133-148.

Saucedo, C. (2005). Los alumnos de la tarde son los peores: prácticas, discursos y posicionamiento de la identidad de alumnos problema en la escuela secundaria. Revista Mexicana de Investigación Educativa, 10 (26), 641-668.

Schmidt, C. J., Pierce, J., \& Stoddard, S. A. (2016). The mediating effect of future expectations on the relationship between neighborhood context and adolescent bullying perpetration. Journal of Community Psychology, 44(2), 232-248. doi: 10.1002/jcop. 21761

Sturge-Apple, M. L., Davies, P. T., \& Cummings, E. M. (2006). Impact of hostility and withdrawal in interparental conflict on parental emotional unavailability and children's adjustment difficulties. Child Development, 77(6), 16231641. doi: 10.1111/j.1467-8624.2006.00963.x

Sutton, J., Reeves, M., \& Keogh, E. (2000). Disruptive behaviour, avoidance of responsibility and theory of mind. British Journal of Developmental Psychology, 18(1), 1-11. doi: 10.1348/026151000165517

Swearer, S. M., \& Hymel, S. (2015). Understanding the psychology of bullying: Moving toward a socialecological diathesis-stress model. American Psychologist, 70(4), 344-353. doi: 10.1037/ a0038929

Turner, H. A., Shattuck, A., Hamby, S., \& Finkelhor, D. (2013). Community disorder, victimization exposure, and mental health in a national sample of youth. Journal of Health and Social Behavior, 54(2), 258-275. doi: 10.1177/0022146513479384

Valdebenito, S., Ttofi, M., \& Eisner, M. (2015). Prevalence rates of drug use among school bullies and victims: A systematic review and metaanalysis of cross-sectional studies. Aggression and Violent Behavior, 23, 137-146. doi: 10.1016/j. avb.2015.05.004 
Valdés, A. A., \& Carlos, E. A. (2017). Relación entre disciplina parental restaurativa, manejo de la vergüenza, compasióny acoso escolar [Relationship among parental restorative discipline, shame management, sympathy, and bullying]. Revista Mexicana de Psicología, 34(1), 37-45.

Valdés, A. A., Carlos, E. A., Tánori, J., \& Madrid, E. J. (2016). Relación entre funcionamiento familiar, emociones morales y violencia entre estudiantes de primaria [Relation between Family Functioning, Moral Emotions, and Violence in Elementary School Students]. Revista Mexicana de Investigación Educativa, 21(71), 1093-1110.

Van Cleave, J., \& Davis, M. M. (2006). Bullying and peer victimization among children with special health care needs. Pediatrics, 118(4), e1212-e1219. doi: 10.1542/peds.2005-3034

Verlinden, M., Jansen, P. W., Veenstra, R., Jaddoe, V. W. V., Hofman, A., Verhulst, F. C., . . . Tiemeier, H. (2015). Preschool Attention-Deficit/ Hyperactivity and Oppositional Defiant Problems as Antecedents of School Bullying. Journal of the American Academy of Child \& Adolescent Psychiatry, 54(7), 571-579. doi: 10.1016/j. jaac.2015.05.002

Vieno, A., Santinello, M., Pastore, M., \& Perkins, D. D. (2007). Social support, sense of community in school, and self-efficacy as resources during early adolescence: an integrative model. American Journal Community Psychology, 39(1-2), 177190. doi: $10.1007 / \mathrm{s} 10464-007-9095-2$

Volk, A. A., Dane, A. V., \& Marini, Z. A. (2014). What is bullying? A theoretical redefinition. Developmental Review, 34(4), 327-343. doi: 10.1016/j.dr.2014.09.001

Werneck, H., Eder, M. O., Yanagida, T., \& Rollett, B. (2014). Predicting adolescents' parent-child relationship quality from parental personality, marital conflict and adolescents' personality. European Journal of Developmental Psychology, 11(2), 159-176. doi: 10.1080/17405629.2013.876914

Wolke, D., Woods, S., Bloomfield, L., \& Karstadt, L. (2000). The association between direct and relational bullying and behaviour problems among primary school children. The Journal of Child Psychology and Psychiatry, 41(8), 9891002. doi: 10.1111/1469-7610.00687

Zani, B., Cicognani, E., \& Albanesi, C. (2001). Adolescents' sense of community and feeling of unsafety in the urban environment. Journal of Community and Applied Social Psychology, 11(6), 475-489. doi: 10.1002/casp.647 